\title{
Biophysical characterization of G-quadruplex forming FMR1 mRNA and of its interactions with different fragile $X$ mental retardation protein isoforms
}

\author{
ANNA C. BLICE-BAUM and MIHAELA-RITA MIHAILESCU ${ }^{1}$ \\ Department of Chemistry and Biochemistry, Duquesne University, Pittsburgh, Pennsylvania 15282, USA
}

\begin{abstract}
Fragile $X$ syndrome, the most common form of inherited mental impairment in humans, is caused by the absence of the fragile $X$ mental retardation protein (FMRP) due to a CGG trinucleotide repeat expansion in the $5^{\prime}$-untranslated region (UTR) and subsequent translational silencing of the fragile $x$ mental retardation-1 (FMR1) gene. FMRP, which is proposed to be involved in the translational regulation of specific neuronal messenger RNA (mRNA) targets, contains an arginine-glycine-glycine (RGG) box RNA binding domain that has been shown to bind with high affinity to G-quadruplex forming mRNA structures. FMRP undergoes alternative splicing, and the binding of FMRP to a proposed G-quadruplex structure in the coding region of its mRNA (named FBS) has been proposed to affect the mRNA splicing events at exon 15. In this study, we used biophysical methods to directly demonstrate the folding of FMR1 FBS into a secondary structure that contains two specific G-quadruplexes and analyze its interactions with several FMRP isoforms. Our results show that minor splice isoforms, ISO2 and ISO3, created by the usage of the second and third acceptor sites at exon 15, bind with higher affinity to FBS than FMRP ISO1, which is created by the usage of the first acceptor site. FMRP ISO2 and ISO3 cannot undergo phosphorylation, an FMRP posttranslational modification shown to modulate the protein translation regulation. Thus, their expression has to be tightly regulated, and this might be accomplished by a feedback mechanism involving the FMRP interactions with the G-quadruplex structures formed within FMR1 mRNA.
\end{abstract}

Keywords: FMRP; G-quadruplex RNA; protein-RNA interactions; fluorescence spectroscopy

\section{INTRODUCTION}

Fragile X syndrome (FXS) is the most common form of inherited intellectual disability in humans (Crawford et al. 2001), affecting $\sim 1$ in 3000 males and 1 in 5000 females (Morton et al. 1997; Hawkins et al. 2011). In the vast majority of the cases, FXS is caused by the absence of a single protein named the fragile $\mathrm{X}$ mental retardation protein (FMRP) required for normal neural function (O'Donnell and Warren 2002; Jin et al. 2004). The gene encoding for this protein, $F M R 1$, is located on the $\mathrm{X}$ chromosome and contains in its $5^{\prime}$-untranslated region ( $5^{\prime}$ UTR) a sequence of cytosine-guanine-guanine (CGG) repeats that is 20-60 repeats in healthy individuals, being expanded to more than 200 repeats in FXS patients (Jin and Warren 2000; O’Donnell and Warren 2002). The cytosines in the expanded region of CGG repeats become hypermethylated, causing the gene silencing of FMR1 and loss of expression of FMRP (Pieretti et al. 1991; Tassone et al. 1999).

\footnotetext{
${ }^{1}$ Corresponding author

E-mail mihailescum@duq.edu

Article published online ahead of print. Article and publication date are at http://www.rnajournal.org/cgi/doi/10.1261/rna.041442.113.
}

FMRP is an RNA binding protein that contains two types of RNA binding domains: two K-homology domains and one arginine-glycine-glycine (RGG) box domain, as well as a nuclear localization signal (NLS) and a nuclear export signal (NES) (Fig. 1; Ashley et al. 1993; Siomi et al. 1993; O’Donnell and Warren 2002). FMRP is postulated to regulate the translation of specific neuronal messenger RNA (mRNA) targets (Darnell et al. 2001) as part of large ribonucleoprotein (mRNP) complexes, although the detailed mechanism of this regulatory process is not well understood. FMRP is post-translationally modified by arginine methylation within the RGG box domain and by serine phosphorylation in a region directly upstream of the RGG box domain (Siomi et al. 2002; Stetler et al. 2006). Additionally, several FMRP isoforms can be produced through alternative splicing events involving the inclusion/skipping of exons 12 and 14, as well as three acceptor sites at exon 15 and two at exon 17 (Verkerk et al. 1993;

\footnotetext{
(c) 2013 Blice-Baum and Mihailescu This article is distributed exclusively by the RNA Society for the first 12 months after the full-issue publication date (see http://rnajournal.cshlp.org/site/misc/terms.xhtml). After 12 months, it is available under a Creative Commons License (AttributionNonCommercial 3.0 Unported), as described at http://creativecommons. org/licenses/by-nc/3.0/.
} 


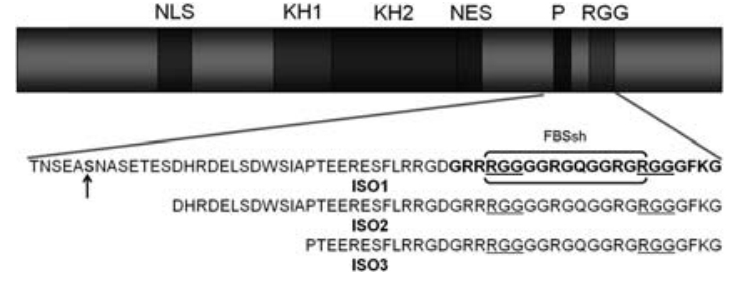

FIGURE 1. A schematic representation of the full-length FMRP, which shows the nuclear localization signal (NLS), the two K-homology domains (KH1 and KH2), the nuclear export signal (NES), the main site of phosphorylation (P), and the RGG box (RGG). An expansion of the sequence differences within isoforms $1-3$, resulting from the alternative splicing at exon 15 of FMR1 mRNA, is also illustrated. The phosphorylation of serine 500 (arrow) has been shown to be biologically relevant. The bracket encompasses the amino acids encoded by the G-rich FBSsh region.

Sittler et al. 1996; Brackett et al. 2013). Figure 1 shows differences in the sequences of the FMRP isoforms 1 (ISO1, the largest FMRP isoform), 2 (ISO2), and 3 (ISO3) created using the three acceptor sites at exon 15 (and inclusive of exons 12 and 14).

Several studies showed that the RGG box domain of FMRP binds with high affinity to mRNA targets that have been shown to adopt G-quadruplex structures (Brown et al. 2001; Darnell et al. 2001; Menon and Mihailescu 2007; Bole et al. 2008; Menon et al. 2008; Evans et al. 2012). G-quadruplexes consist of guanine tetrads held together by Hoogsteen base-pairing and stabilized by monocations, the potassium ion $\left(\mathrm{K}^{+}\right)$providing the most thermodynamic stability (Williamson et al. 1989; Williamson 1994).

FMRP has also been shown to interact with its own mRNA within a 100-nucleotide G-rich region named the FMRP binding sequence (FBS), which was proposed to fold into two distinct G-quadruplex structures (Schaeffer et al. 2001, 2003; Didiot et al. 2008). This finding prompted the hypothesis that FMRP might use an autoregulatory loop to regulate its own translation; however, a subsequent study has shown that the FMRP interactions with FBS do not affect the FMR1 mRNA stability and translation (Didiot et al. 2008). The purine-rich FBS region has been found instead to be a potent exonic splicing enhancer whose function is dependent on the presence of the G-rich region (Didiot et al. 2008). FBS is located in the proximity of the three different acceptor sites at exon 15, and FMRP binding to FBS has been found to control the splicing events at exon 15. An overexpression of FMRP ISO1 decreased the usage of exon 15 first acceptor site, concomitant with an increased usage of exon 15 second and third acceptor sites, whereas the absence of FMRP resulted in the absence of the minor isoforms created by the usage of exon 15 second and third acceptor sites (Didiot et al. 2008). This direct involvement of FMRP in regulating the production of its minor isoforms created by the usage of exon 15 acceptor sites 2 and 3 (which include FMRP ISO2 and ISO3) could add a new layer of regulation to the FMRP translation regulator function, as these isoforms lack the major phos- phorylation site at position 500 (Fig. 1, arrow). The FMRP phosphorylation/dephosphorylation events have been shown to play a major role in the association of FMRP with the miRNA pathway (Muddashetty et al. 2011), as phosphorylated FMRP has been found associated with the RNA interference silencing complex (RISC), the microRNA miR-125a, and the postsynaptic density 95 (PSD95) mRNA; whereas its dephosphorylation triggered by synaptic input leads to the dissociation of the RISC complex from PSD95 mRNA, allowing for the translation of the PSD95 protein (Zalfa et al. 2007; Muddashetty et al. 2011). The fact that FMRP isoforms ISO2 and ISO3 lack the major site of phosphorylation raises the possibility that these minor isoforms could finetune the FMRP translation regulator function by controlling the duration different mRNA targets are undergoing translation. Thus, their production has to be tightly regulated, and this might be achieved by a feedback mechanism involving the FBS exonic splicing enhancer. In this study, we have first used biophysical methods to characterize the G-quadruplex structures proposed to form in the FMR1 mRNA FBS and subsequently analyzed the binding of several FMRP isoforms (ISO1, ISO2, ISO3), as well as of a mimic of phosphorylated FMRP ISO1 (ISO1 S500D) to a 42-nucleotide FBS fragment.

\section{RESULTS AND DISCUSSION}

\section{Biophysical characterization of the FMR1 mRNA G-quadruplex structures}

Moine and coworkers proposed that two G-quadruplex structures form in the $\mathrm{C}$ terminus of FMR1 mRNA in a 100-nt stretch (FBS) (Schaeffer et al. 2001, 2003; Didiot et al. 2008) based on potassium-dependent stops of reverse-transcription that disappeared when mutations were introduced in the G-rich region recognized by FMRP. In this study, we used biophysical methods to directly prove the existence and characterize the fold of the G-quadruplex structures in FMR1 mRNA. Initially, we truncated FBS to a 67-nt fragment (position 1590-1657 within the FMR1 gene), named FBS_67 RNA, that retained the G-rich region proposed to fold into the two G-quadruplex structures. FBS_67 RNA has been produced by in vitro transcription reactions off a synthetic DNA template and one dimensional (1D) ${ }^{1} \mathrm{H}$ NMR spectroscopy has been used to analyze G-quadruplex formation within FBS_67 in the presence of $\mathrm{KCl}$. A broad envelope of imino proton resonances centered around $11 \mathrm{ppm}$, which correspond to guanine imino protons involved in G-quartet formation, was observed even in the absence of $\mathrm{K}^{+}$ions (Supplemental Fig. 1A). Resonances were also observed in the region 12-14.5 ppm, corresponding to guanine and uracil imino protons involved in Watson-Crick base-pair formation, indicating also the presence of a duplex region in the structure of FBS_67 RNA.

As the $\mathrm{KCl}$ concentration was increased in the range of $0-$ $100 \mathrm{mM}$, the resonances corresponding to the imino protons 
involved in G-quartet formation increased in intensity and became sharper, whereas the intensity of the resonances corresponding to canonical base-pairing remained constant. These results indicate unambiguously that one or more Gquadruplex structures that are stabilized by $\mathrm{K}^{+}$ions are present in FBS_67 RNA. Circular dichroism (CD) spectroscopy was used next to characterize the G-quadruplex fold of FBS_67 RNA, and a positive band whose intensity increased upon $\mathrm{KCl}$ titration was observed at $264 \mathrm{~nm}$ and a negative one at $240 \mathrm{~nm}$, signatures of parallel-type G-quadruplex structures (Supplemental Fig. 1B; Williamson 1994; Dapic et al. 2003). Nondenaturing polyacrylamide gel electrophoresis (native PAGE) was also used to analyze FBS_67, several bands being observed at all RNA and $\mathrm{KCl}$ concentrations investigated in the range of $0-100 \mathrm{mM}$, which indicates that multiple conformations coexist in FBS_67 RNA (data not shown). In an attempt to solve this problem, we have produced by in vitro transcription reactions two shorter fragments of FBS: FBS_Q1 RNA (15 nt, position 1602-1616 within the FMR1 gene) and FBS_Q2 RNA (19 nt, position 1617-1635 within the FMR1 gene) whose sequences were predicted to adopt G-quadruplex structures (Table 1).

First, we used native PAGE to analyze the conformations of FBS_Q1 and FBS_Q2 in the presence of increasing $\mathrm{KCl}$ concentrations. Two bands exist for FBS_Q1 in the absence of $\mathrm{KCl}$ (Fig. 2A, left, lane 1), which collapse into a single band once $\mathrm{KCl}$ is titrated in the sample (Fig. 2A, left, lanes 2,3). In contrast, a single band exists for FBS_Q2 at all $\mathrm{KCl}$ concentrations investigated (Fig. 2A, right, lanes 1-3).

Next, we used $1 \mathrm{D}{ }^{1} \mathrm{H}-\mathrm{NMR}$ spectroscopy to investigate Gquadruplex formation within each of these two RNA sequences. For FBS_Q1 RNA, resonances corresponding to imino protons of guanines involved in G-quartet formation were observed in the region 10-11.5 ppm, even in the absence of $\mathrm{KCl}$ (Fig. 2B). Upon titration of $\mathrm{KCl}$ up to $25 \mathrm{mM}$, these imino proton resonances became sharper, indicating that the FBS_Q1 G-quadruplex is stabilized by $\mathrm{K}^{+}$ions, and the annealing of the sample resulted in the sharpest resonances (Fig. 2B, top spectrum). Thus, all further experiments were performed with annealed FBS_Q1 RNA samples. No imino proton resonances corresponding to Watson-Crick base pairs were observed in the region 12-15 ppm, indicating the absence of an alternate duplex conformation. It is interesting to note the presence of two unusually sharp and downfield-shifted guanine amino resonances at $10.0 \mathrm{ppm}$ and $9.9 \mathrm{ppm}$. A second set of sharp and downfield-shifted amino protons were observed at 8.8 and $8.6 \mathrm{ppm}$. Sharp and downfield-shifted guanine amino proton resonances observed in G-quadruplex forming sequences containing GGAGG stretches have been attributed to the presence of an A:(G:G:G:G):A hexad in the structure, in which two guanines have both their amino protons hydrogen bonded, one to a neighboring $\mathrm{G}$ in the G-tetrad and the second to the N7 of the adenine to form a hexad (Fig. 2C, right; Kettani et al. 2000; Liu et al. 2002; Mergny et al. 2006; Matsugami et al. 2008; Lipay and Mihailescu 2009). ${ }^{1} \mathrm{H}-{ }^{1} \mathrm{H}$ two-dimensional (2D) nuclear Overhauser enhancement NMR spectroscopy (NOESY) experiments revealed strong NOE cross peaks between the amino proton pairs at $(10.0 \mathrm{ppm} ; 8.8 \mathrm{ppm})$ and $(9.9 \mathrm{ppm} ; 8.6 \mathrm{ppm})$. Additionally, strong NOEs were observed between each of these sharp amino protons and their corresponding imino proton at (10.0 ppm; $11.5 \mathrm{ppm}),(8.8 \mathrm{ppm} ; 11.5 \mathrm{ppm})$ and (9.9 ppm; $11.3 \mathrm{ppm}),(8.6 \mathrm{ppm} ; 11.3 \mathrm{ppm})$, respectively (Supplemental Fig. 2A). This result is consistent with the presence of a hexad structure in which two guanines have both amino protons involved in hydrogen bonding. Next, we performed proton-deuterium exchange experiments, which revealed that the same set of imino protons (at $11.5 \mathrm{ppm}$ and $11.3 \mathrm{ppm}$ ), and amino proton pairs (at $10.0 \mathrm{ppm}, 8.8 \mathrm{ppm}$ and $9.9 \mathrm{ppm}, 8.6 \mathrm{ppm}$, respectively) for which we observed strong NOE cross peaks in the NOESY experiments, exchange very slowly (hours or days) compared to the rest of the imino protons present in the spectrum (minutes) (Supplemental Fig. 2B). This exchange with the solvent, which requires the base pairs opening, is slowed down considerably when both amino protons of some the guanines are involved in hydrogen bonds, as predicted in the hexad structure (Fig. 2C). Taken together, these results strongly suggest that the FBS_Q1 sequence adopts a G-quadruplex, which contains an A:(G:G: G:G):A hexad (Fig. 2C, left).

When FBS_Q2 was analyzed by $1 \mathrm{D}^{1} \mathrm{H}-\mathrm{NMR}$ spectroscopy, a set of resonances corresponding to the imino protons of Gs and Us involved in Watson-Crick base pairs were observed in the region 12-14 ppm at all $\mathrm{KCl}$ concentrations investigated, whereas the characteristic G-quadruplex imino proton resonances centered around $11 \mathrm{ppm}$ were not observed until 25 $\mathrm{mM} \mathrm{KCl}$ was titrated in the sample (Fig. 2D). The G-quadruplex imino proton resonances increased in intensity as $\mathrm{KCl}$

TABLE 1. FMR1 oligonucleotide sequences used in this study

\begin{tabular}{|c|c|}
\hline RNA name & RNA sequence \\
\hline FBS_67 RNA & 5'-GGACGGCGGCGUGGAGGGGGAGGAAGAGGACAAGGAGGAAGAGGACGUGGAGGAGGCUUCAAAGGAA-3'a \\
\hline FBS_Q1 RNA & 5'-GGAGGGGGAGGAAGA-3'a \\
\hline FBS_Q2 RNA & 5'-GGACAAGGAGGAAGAGGAC-3'a \\
\hline FBSsh RNA & 5'-GGCGUGGAGGGGGAGGAAGAGGACAAGGAGGAAGAGGACGUG-3'a \\
\hline
\end{tabular}

${ }^{a}$ Bolded nucleotides are proposed to be involved in G-quadruplex formation. 
A

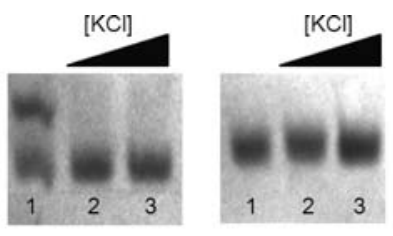

B

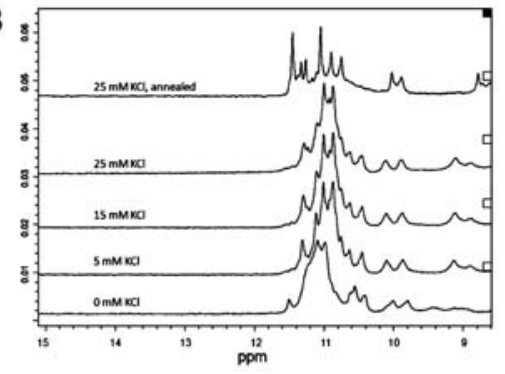

C

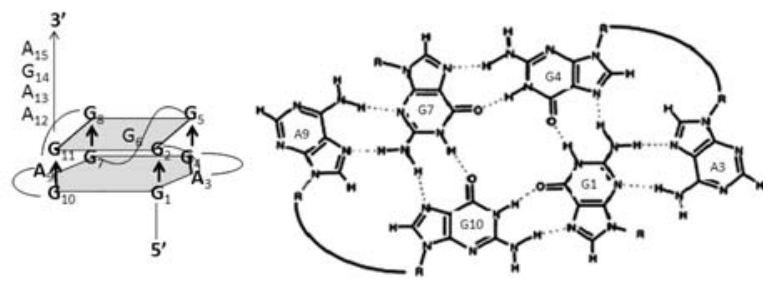

D

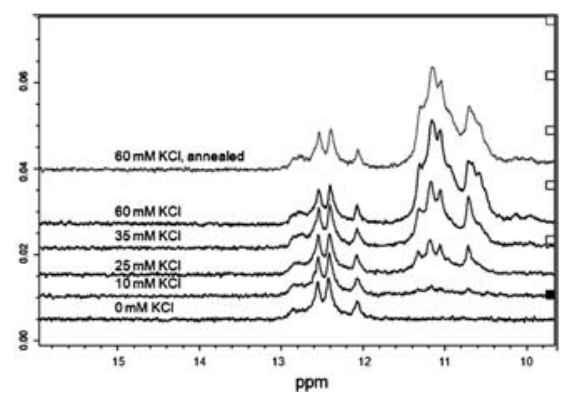

FIGURE 2. (A) Native PAGE of FBS_Q1 RNA (left) and FBS_Q2 RNA (right) in the presence of increasing $\mathrm{KCl}$ concentrations: $10 \mu \mathrm{M}$ RNA at $0 \mathrm{mM} \mathrm{KCl}$ (lane 1), $25 \mathrm{mM} \mathrm{KCl}$ (lane 2), and $50 \mathrm{mM} \mathrm{KCl}$ (lane 3). The gels were visualized by UV shadowing at $254 \mathrm{~nm}$. (B) $1 \mathrm{D}{ }^{1} \mathrm{H}-\mathrm{NMR}$ spectra of $1.1 \mathrm{mM}$ FBS_Q1 RNA in $10 \mathrm{mM}$ cacodylic acid, pH 6.5, in the presence of increasing $\mathrm{KCl}$ concentrations in the range of $0-25 \mathrm{mM}$. (C) Proposed structure of FBS_Q2 (left); A:(G:G:G:G):A hexad formed by two adenines that are in the plane with the G-quartet (right). The formation of a hexad stabilizes the amino protons that are involved in Hoogsteen base-pairing within the G quartet. $(D) 1 \mathrm{D}^{1} \mathrm{H}-\mathrm{NMR}$ spectra of 1.1 mM FBS_Q2 RNA in $10 \mathrm{mM}$ cacodylic acid, pH 6.5, in the presence of increasing $\mathrm{KCl}$ concentrations in the range of $0-60 \mathrm{mM}$.

was titrated in FBS_Q2; however, the intensity of the imino proton resonances corresponding to Watson-Crick base pairs remained unaffected, suggesting that FBS_Q2 adopts a Gquadruplex structure stabilized by $\mathrm{K}^{+}$ions but also an alternative conformation involving Watson-Crick base pairs.

To determine if the FMRP RGG box peptide binds to the G-quadruplex structures formed by FBS_Q1 and FBS_Q2 RNAs, native PAGE was performed on each sequence in the presence of $\mathrm{KCl}$. Because the RGG box peptide has an overall positive charge due to its high arginine/lysine content, the
RGG-RNA complex does not give rise to a tight band in the native PAGE; thus, the binding of RGG box peptide to RNA is monitored by the loss of the free RNA band in the gel. The FBS_Q1 free RNA band nearly disappears in the presence of a 2:1 ratio of RGG box: RNA (Fig. 3A, lane 4), whereas the intensity of the FBS_Q2 free RNA band does not change significantly in the presence of the same ratio of RGG box: RNA. This result indicates that the FMRP RGG box peptide does not have a strong binding affinity for FBS_Q2 RNA.

\section{FBSsh RNA forms a G-quadruplex structure}

Next, we inquired if the A:(G:G:G:G):A hexad in FBS_Q1 was also formed when FBS_Q1 is located in the context of its larger surrounding sequence within FMR1 mRNA. Thus, we combined FBS_Q1 and FBS_Q2 RNAs to form a 42-nt fragment, named FBSsh RNA (nucleotides 1597-1638 within the FMR1 gene) (Table 1). The imino proton region of the 1D ${ }^{1} \mathrm{H}-\mathrm{NMR}$ spectrum of FBSsh RNA shows a broad resonance in the region between 10 and $11.5 \mathrm{ppm}$, corresponding to imino protons of guanines involved in G-quartet formation, even in the absence of $\mathrm{KCl}$ (Fig. 4A). Upon the addition of $\mathrm{KCl}$ up to $25 \mathrm{mM}$, more defined resonances develop under this broad envelope, indicating that the G-quadruplex structures of FBSsh RNA are further stabilized in the presence of $\mathrm{K}^{+}$ions. Nonetheless, at all $\mathrm{KCl}$ concentrations investigated, the G-quadruplex imino proton resonances remain broad, which could be due to the presence of dynamic G-quadruplex structures in FBSsh. Interestingly, no sharp amino proton resonances, signatures of the A:(G:G:G:G):A hexad, were observed around $10 \mathrm{ppm}$, indicating that this structure is not formed in FBSsh but is likely induced in the isolated FBS_Q1 by the short length of the sequence. Additionally, in contrast to the 1D ${ }^{1} \mathrm{H}$-NMR spectra of FBS_Q2 RNA, no resonances appear in the Watson-Crick base-pair region of the ${ }^{1} \mathrm{H}-\mathrm{NMR}$ spectrum of FBSsh RNA, indicating that this sequence does not form any alternate conformations involving WatsonCrick base pairs.
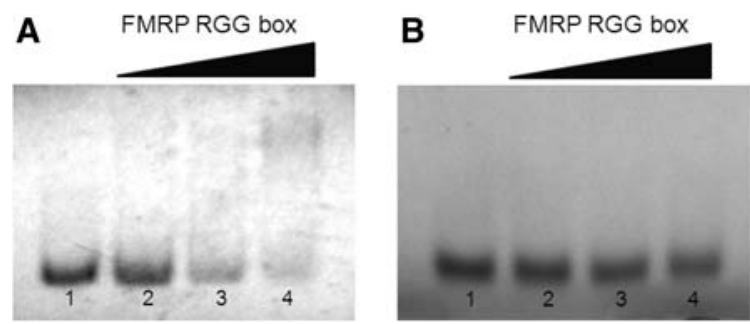

FIGURE 3. (A) Native PAGE of $30 \mu \mathrm{M}$ FBS_Q1 RNA in $25 \mathrm{mM} \mathrm{KCl}$ in the presence of increasing concentrations of FMRP RGG box peptide: $0 \mu \mathrm{M}$ RGG box (lane 1), $15 \mu \mathrm{M}$ RGG box (lane 2), $30 \mu \mathrm{M}$ RGG box (lane 3 ), and $60 \mu \mathrm{M}$ RGG box (lane 4). (B) Native PAGE of $30 \mu \mathrm{M}$ FBS_Q2 RNA in $25 \mathrm{mM} \mathrm{KCl}$ in the presence of increasing concentrations of FMRP RGG box peptide: $0 \mu \mathrm{M}$ RGG box (lane 1 ), $15 \mu \mathrm{M}$ RGG box (lane 2), $30 \mu \mathrm{M}$ RGG box (lane 3), and $60 \mu \mathrm{M}$ RGG box (lane 4). The gels were visualized by UV shadowing at $254 \mathrm{~nm}$. 

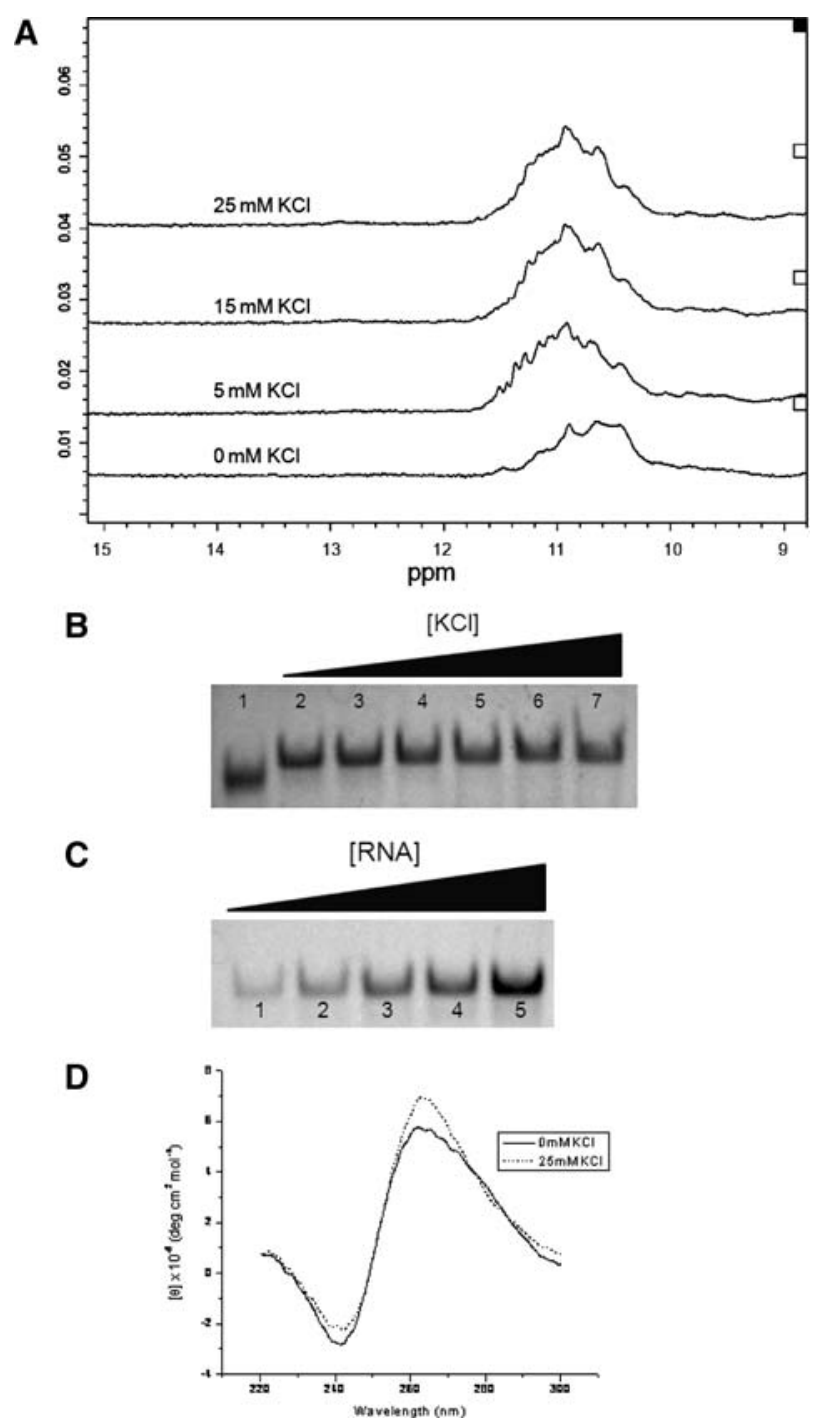

FIGURE 4. (A) $1 \mathrm{D}^{1} \mathrm{H}-\mathrm{NMR}$ spectra of $334 \mu \mathrm{M}$ FBSsh RNA in $10 \mathrm{mM}$ cacodylic acid, $\mathrm{pH} 6.5$, in the presence of increasing $\mathrm{KCl}$ concentrations in the range of $0-25 \mathrm{mM}$. (B) Native PAGE of a fixed concentration of $10 \mu \mathrm{M}$ FBSsh RNA in the presence of increasing concentrations of $\mathrm{KCl}$ in the range of $0-150 \mathrm{mM}$. $(C)$ Native PAGE of increasing concentrations of FBSsh RNA in the range of 5-30 $\mu \mathrm{M}$ in the presence of $25 \mathrm{mM} \mathrm{KCl}$. Gels were visualized by UV shadowing at $254 \mathrm{~nm}$. (D) CD spectra of $10 \mu \mathrm{M}$ FBSsh RNA in $10 \mathrm{mM}$ cacodylic acid, pH 6.5, at $0 \mathrm{mM} \mathrm{KCl}$, and $25 \mathrm{mM} \mathrm{KCl}$.

Native PAGE was used next to analyze FBSsh RNA in the presence of different $\mathrm{KCl}$ concentrations. At $0 \mathrm{mM} \mathrm{KCl}$, FBSsh RNA migrates in the gel as a single band (Fig. 4B, lane 1), which changes position with increasing salt concentrations up to $150 \mathrm{mM} \mathrm{KCl} \mathrm{(Fig.} \mathrm{4B,} \mathrm{lanes} \mathrm{2-7).} \mathrm{Similarly,} \mathrm{a}$ single band was observed when several concentrations of FBSsh RNA in the range of 5-30 $\mu \mathrm{M}$ were analyzed by native PAGE in the presence of a fixed concentration of $25 \mathrm{mM} \mathrm{KCl}$ (Fig. 4C, lanes 1-5).

To gain additional information about the fold of the Gquadruplexes within FBSsh RNA, we used CD spectroscopy.
The CD spectrum of FBSsh RNA shows a negative band at $240 \mathrm{~nm}$ and a positive band at $265 \mathrm{~nm}$ that increase in intensity upon the titration of $\mathrm{KCl}$ from 0 to $25 \mathrm{mM}$ (Fig. 4D). This result, which indicates that one or more parallel G-quadruplex structures are present in FBSsh RNA, is consistent with the ${ }^{1} \mathrm{H}-\mathrm{NMR}$ spectra of FBSsh RNA, which showed an increase in the intensities of the G-quartet imino proton resonances upon the titration of $\mathrm{K}^{+}$ions.

Next, we used thermodynamic methods to determine if the FBSsh RNA folds into an intermolecular or intramolecular conformation. Specifically, the melting temperatures of the FBSsh G-quadruplex structures at various RNA concentrations in the presence of $25 \mathrm{mM} \mathrm{KCl}$ were measured by UV thermal denaturation. The melting temperature, $T_{m}$, for a species containing $n$ number of strands depends on the total RNA concentration, $c_{T}$ (Equation 1; Hardin et al. 2000):

$$
\begin{aligned}
\frac{1}{T_{m}}= & \frac{R(n-1)}{\Delta H_{v H}^{\mathrm{o}}} \ln c_{T} \\
& +\frac{\Delta S_{v H}^{\mathrm{o}}-(n-1) R \ln 2+R \ln n}{\Delta H_{v H}^{\mathrm{o}}} .
\end{aligned}
$$

For intramolecular species, $n=1$, and $T_{m}$ is independent of $c_{T}$ (Equation 2):

$$
\frac{1}{T_{m}}=\frac{\Delta S_{v H}^{\mathrm{o}}}{\Delta H_{v H}^{\mathrm{o}}} .
$$

The experiments were recorded at $295 \mathrm{~nm}$, a wavelength shown to be sensitive to G-quadruplex denaturation (Mergny et al. 1998). The UV thermal denaturation of FBSsh RNA at $295 \mathrm{~nm}$ in the presence of $25 \mathrm{mM} \mathrm{KCl}$ revealed two distinct hypochromic transitions characteristic of the denaturing of a G-quadruplex with melting temperatures of $T_{m} \sim$ $42^{\circ} \mathrm{C}$ and $T_{m} \sim 69^{\circ} \mathrm{C}$, respectively (Fig. $5 \mathrm{~A}$ ), consistent with the presence of two distinct G-quadruplex structures in FBSsh RNA. Figure 5B shows a model of the two individual G-quadruplexes proposed to form within FBSsh RNA as the combination of FBS_Q1 RNA and FBS_Q2 RNA.

To determine if the FBSsh G-quadruplexes are intramolecular, increasing concentrations of FBSsh RNA in the range of 3-30 $\mu \mathrm{M}$ were UV thermally denatured in the presence of $25 \mathrm{mM} \mathrm{KCl}$. As Figure 5C shows, the $T_{m}$ of each transition remained constant at $42^{\circ} \mathrm{C}$ and $69^{\circ} \mathrm{C}$, respectively, independent of the RNA concentration, indicating that each of the two G-quadruplex structures formed in FBSsh RNA is intramolecular (Fig. 5B,C; Equation 2).

Based solely on the UV thermal denaturation experiments, it is not possible to assign the two hypochromic transitions to the FBS_Q1 and FBS_Q2 G-quadruplexes. Thus, we constructed a fluorescently labeled RNA by replacing the adenine at position 14 of FBSsh RNA with 2-aminopurine (2AP) (FBSsh_14AP RNA, circled in Fig. 5B), which reports only on the melting of the first quadruplex in the sequence, FBS_Q1 RNA. 2AP is a highly fluorescent analog of adenine, which is sensitive to changes in its microenvironment 
A
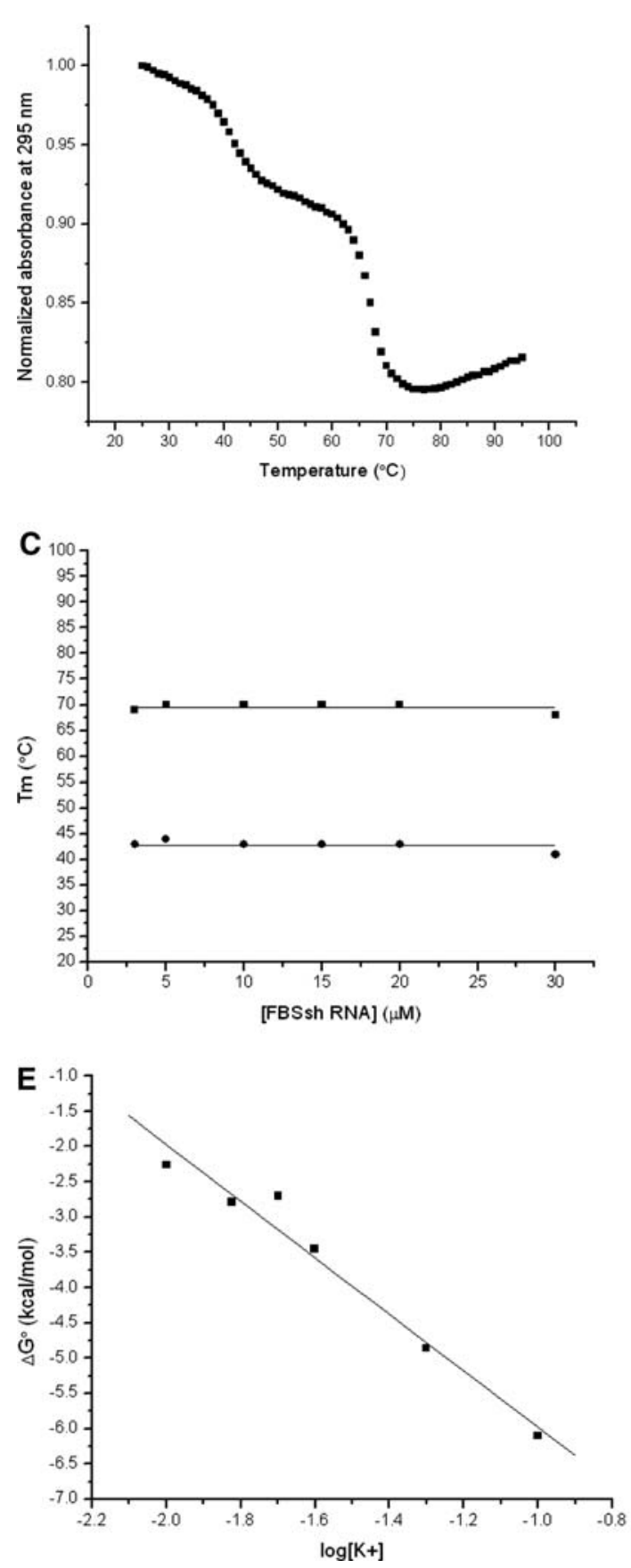

B

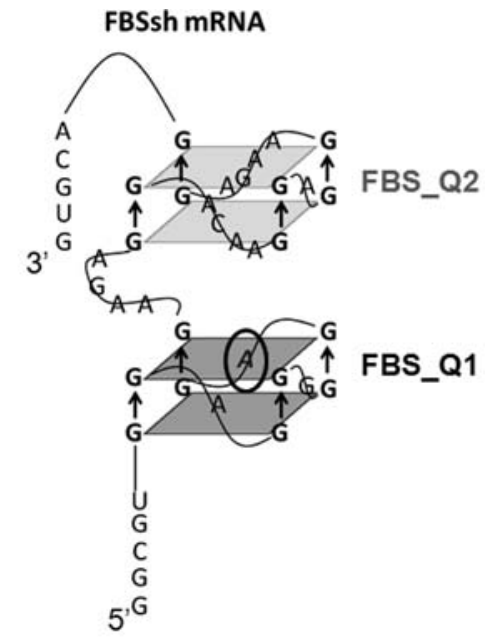

\section{D}
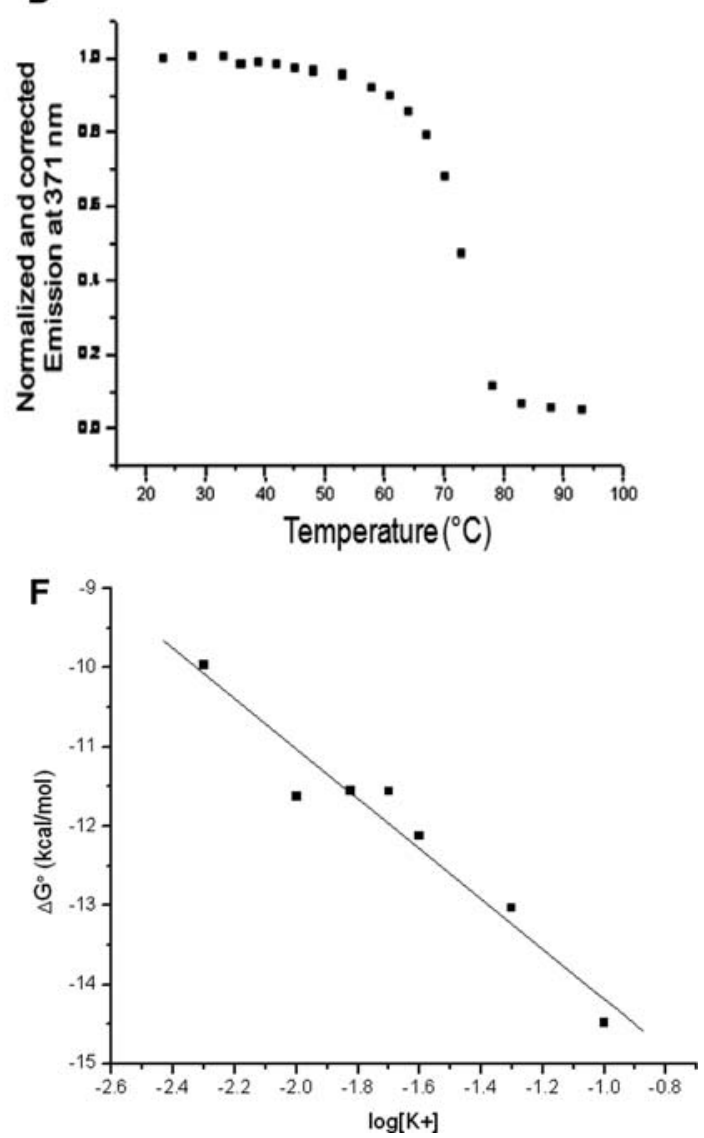

FIGURE 5. (A) UV thermal denaturation curve of $10 \mu \mathrm{M}$ FBSsh RNA in $10 \mathrm{mM}$ cacodylic acid, pH 6.5, containing $25 \mathrm{mM}$ KCl. (B) Model of FBSsh RNA showing the combination of the two G-quadruplexes formed by FBS_Q1 RNA and FBS_Q2 RNA. (C) Melting temperatures of both G-quadruplex structures of FBSsh RNA plotted against the RNA concentration. (D) Fluorescence spectroscopy thermal denaturation of $150 \mathrm{nM}$ FBSsh_14AP RNA in $10 \mathrm{mM}$ cacodylic acid, pH 6.5, and $25 \mathrm{mM} \mathrm{KCl}$. (E) Plot of $\Delta \mathrm{G}^{\circ}$ as a function of the logarithm of $\mathrm{K}^{+}$ion concentration for FBS_Q2. (F) Plot of $\Delta \mathrm{G}^{\circ}$ as a function of the logarithm of $\mathrm{K}^{+}$ion concentration for FBS_Q1.

(Serrano-Andres et al. 2006; Bharill et al. 2008). In contrast to UV thermal denaturation in which the change in absorbance as a function of temperature has contributions from all nucleotides in the sequence, thermal denaturation using fluorescence spectroscopy monitors only the changes in the steady-state fluorescence of the 2AP reporter, hence only the melting of the FBS_Q1 quadruplex. FBSsh_14AP RNA was thermally denatured in the presence of $25 \mathrm{mM} \mathrm{KCl}$ (Fig. 5D), each temperature point of the steady-state fluorescence being corrected to account for the dependence of the 
free fluorophore emission upon temperature. As expected, a single transition was observed for FBSsh_14AP, which was fitted with Equation 3, which assumes a two-state model:

$$
A(T)=\frac{A_{U}+A_{F} e^{\left(-\Delta H^{\circ} / R T\right)} e^{\left(\Delta S^{\circ} / R\right)}}{e^{\left(-\Delta H^{\circ} / R T\right)} e^{\left(\Delta S^{\circ} / R\right)}+1},
$$

yielding a $T_{m}$ of $69.6 \pm 0.1^{\circ} \mathrm{C}$ (Supplemental Fig. 3A). This result is in very good agreement with the $T_{m}$ value of $68.8 \pm 1.0^{\circ}$ $\mathrm{C}$ determined when the UV thermal denaturation for transition 2 was fitted with Equation 3 (Supplemental Fig. 3B). Thus, we assign transition 2 to the melting of the FBS_Q1 G-quadruplex and transition 1 to the melting of the FBS_Q2 G-quadruplex within FBSsh RNA. These results are consistent with the literature, as it has been shown that the length of the loops connecting the G-quartet planes affects the stability of the G-quadruplex structure, with shorter loops forming tighter, more thermodynamically stable structures (Guedin et al. 2010). FBS_Q1 has single nucleotide connecting loops, and thus this structure was expected to have a higher melting point than FBS_Q2, which has longer connecting loops on two sides of its structure (Fig. 5B).

Next, the number of $\mathrm{K}^{+}$ions coordinating each of the two G-quadruplexes was determined by performing UV thermal denaturation experiments at a fixed FBSsh RNA concentration of $10 \mu \mathrm{M}$ and variable $\mathrm{KCl}$ concentrations in the range of 5$150 \mathrm{mM}$. The $\Delta \mathrm{G}^{\circ}$ of each of the two transitions, calculated using the thermodynamic parameters obtained by fitting the data at each $\mathrm{KCl}$ concentration with Equation 3, was plotted as a function of $\log \left[\mathrm{K}^{+}\right]$according to Equation 4 (Fig. 5E,F):

$$
\Delta n=\frac{d \ln K_{\mathrm{eq}}}{d \ln \left[K^{+}\right]}=-\frac{\Delta \Delta G^{\mathrm{o}}}{2.3 R T \Delta \log \left[K^{+}\right]} .
$$

The number of $\mathrm{K}^{+}$ions coordinated to each G-quadruplex was determined from the negative slope of the plots (Fig. $5 \mathrm{E}, \mathrm{F})$ to be $\sim 3 \mathrm{~K}^{+}$ions for each G-quadruplex in FBSsh RNA. It is well documented in the literature that $\mathrm{K}^{+}$ions are present in the central ion channel of G-quadruplex structures at the center of two successive G quartets (Wei et al. 2012). However, more recently it has been shown that these ions also bind specifically to and stabilize the G-quadruplex loops (Gray and Chaires 2011; Wei et al. 2012). Since each of the FBS_Q1 and FBS_Q2 G-quadruplex structures are proposed to contain two G-quartet planes (Fig. 5B), it is possible that one $\mathrm{K}^{+}$ion is present in the central channel of each structure, whereas the other two coordinate the surrounding loops. Alternately, the FBS_Q1 and FBS_Q2 structures might stack upon each other, creating an additional binding site for $\mathrm{K}^{+}$ within the central channel.

Taken together, our $1 \mathrm{D}{ }^{1} \mathrm{H}$ NMR spectroscopy, UV thermal denaturation, and $\mathrm{CD}$ spectroscopy results prove that FBSsh RNA folds into two intramolecular parallel G-quadruplex structures, in agreement with the proposal that two Gquadruplexes exist within the FBS region of the FMR1 mRNA (Schaeffer et al. 2001).

\section{FBSsh RNA interactions with different FMRP isoforms}

FMRP ISO1 has been shown to influence the FMR1 mRNA alternative splicing events at exon 15 by increasing the production of the minor isoforms created by the usage of the second and third acceptor site. Alternately, in the absence of FMRP ISO1, the mRNAs encoding for these minor isoforms are not detected in $F M R 1^{-1-}$ mice that do not produce FMRP but still produce FMR1 mRNA (Didiot et al. 2008). These results clearly indicate that FMRP ISO1 regulates the alternative splicing of FMR1 through its interactions with the G-quadruplex forming FBS, but the exact mechanism by which this is accomplished has not been elucidated. In an effort to gain additional insight about this mechanism, we used fluorescence spectroscopy to obtain quantitative information about the interactions of FMRP with FBSsh RNA. Several FMRP isoforms were analyzed-FMRP ISO1, ISO2, and ISO3 - created by the usage of the three different acceptor sites at exon 15 located in the close proximity of FBS, all of which contain an identical RGG box, the FMRP domain shown to bind with high affinity to G-quadruplex RNA (Darnell et al. 2001; Bole et al. 2008; Evans et al. 2012; Brackett et al. 2013). Additionally, since phosphorylation of FMRP has been shown to be important in mediating its translation regulator function (Ceman et al. 2003; Muddashetty et al. 2011), we inquired if this post-translational modification may also play a role in the regulation of the alternative splicing of FMR1 mRNA by analyzing the interactions with FBS of an isomimetic of phosphorylated FMRP, FMRP ISO1 S500D, created by mutating the serine at position 500 by aspartic acid (Tarrant and Cole 2009; Coffee et al. 2011; Muddashetty et al. 2011). Recombinant FMRP isoforms ISO1, ISO2, ISO3, and ISO1 S500D were expressed in E. coli and purified by nickel affinity column purification as described (Laggerbauer et al. 2001; Evans and Mihailescu 2010). In these studies, we have used FBSsh_14AP RNA, constructed by replacing the adenine at position 14 located within the FBS_Q1 G-quadruplex by $2 \mathrm{AP}$ (circled in Fig. 5B) described above.

Each FMRP isoform-ISO1, ISO2, ISO3, and ISO1 S500D -was titrated into a fixed concentration of FBSsh_14AP $\mathrm{RNA}$, monitoring the changes in the steady state fluorescence intensity of the 2AP reporter located within the FBS_Q1 quadruplex (Fig. 6A-D), and the dissociation constant, $K_{\mathrm{d}}$, of the complex formed by each FMRP isoform with FBSsh_14AP RNA was determined from the fits of the binding curves with Equation 5 (Table 2; Materials and Methods).

All FMRP isoforms investigated bind with low $\mathrm{nM} K_{\mathrm{d}}$ values to FBSsh_14AP RNA (Table 2), consistent with previous findings that FMRP binds G-quadruplex forming RNA with high affinity (Evans et al. 2012). For example, the $K_{\mathrm{d}}=(120 \pm$ 17) nM determined for FMRP ISO1 binding to FBSsh_14AP RNA is within error from the $K_{\mathrm{d}}=(104 \pm 11) \mathrm{nM}$ value determined for the binding of FMRP ISO1 to the G-quadruplex forming semaphorin 3F RNA, another FMRP target (Evans et al. 2012). FMRP ISO1 and ISO1 S500D bind with similar 

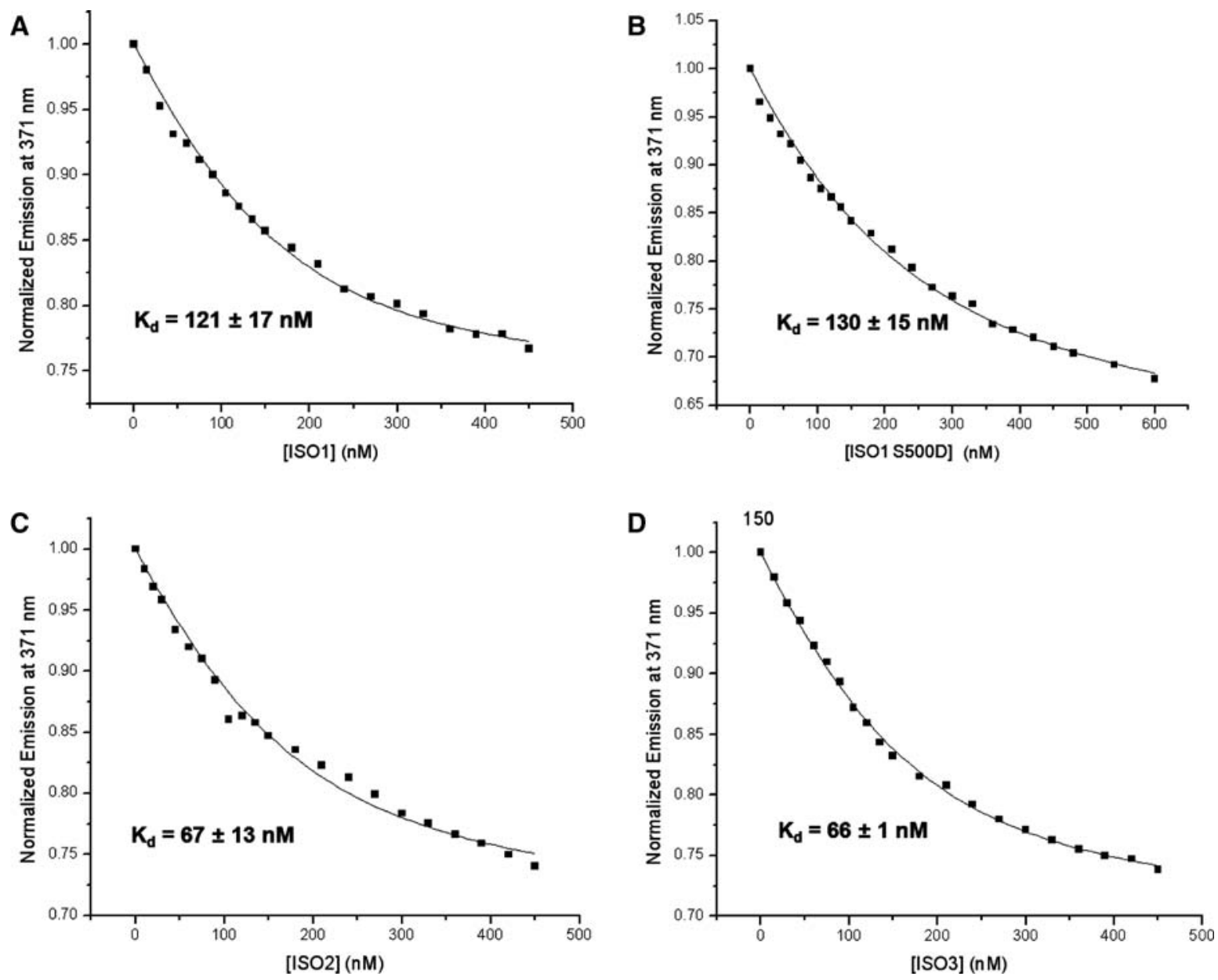

FIGURE 6. (A) FMRP ISO1 titrated into $150 \mathrm{nM}$ FBSsh_14AP RNA in $10 \mathrm{mM}$ cacodylic acid, pH 6.5, $750 \mathrm{nM}$ BSA, and $25 \mathrm{mM}$ KCl. (B) FMRP ISO1 S500D titrated into $150 \mathrm{nM}$ FBSsh_14AP RNA in $10 \mathrm{mM}$ cacodylic acid, $\mathrm{pH} 6.5,750 \mathrm{nM} \mathrm{BSA}$, and $25 \mathrm{mM} \mathrm{KCl}$. (C) FMRP ISO2 titrated into $150 \mathrm{nM}$ FBSsh_14AP RNA in $10 \mathrm{mM}$ cacodylic acid, pH 6.5, $750 \mathrm{nM} \mathrm{BSA}$, and $25 \mathrm{mM} \mathrm{KCl}$. (D) FMRP ISO3 titrated into $150 \mathrm{nM}$ FBSsh_14AP RNA in 10 mM cacodylic acid, $\mathrm{pH} 6.5,750 \mathrm{nM} \mathrm{BSA}$, and $25 \mathrm{mM} \mathrm{KCl}$. Figures show a representative curve of the experiments performed in triplicate. The $x$-axis represents the total protein concentration $[P]_{t}$ from Equation 5 (Materials and Methods) for each FMRP isoform investigated.

affinity to FBSsh_14AP RNA $\left[K_{\mathrm{d}}=(120 \pm 17)\right.$ nM versus $K_{\mathrm{d}}$ $=(130 \pm 15) \mathrm{nM}]$, indicating that the binding of FMRP ISO1 to its own mRNA sequence is not affected by the mutation of S500D, which mimics the post-translational modification of phosphorylation. The phosphorylation of Ser500 has been shown to be important in the exertion of the FMRP translation regulator function on some of its target mRNAs (Ceman et al. 2003; Muddashetty et al. 2011); however, no quantitative data are available regarding the binding of phosphorylat-

TABLE 2. FMRP isoform-FBSsh_14AP RNA complex dissociation constants

\begin{tabular}{lc}
\hline FMRP isoform & $K_{\mathrm{d}}(\mathrm{nM})$ \\
\hline ISO1 & $120 \pm 17$ \\
ISO2 & $67 \pm 13$ \\
ISO3 & $66 \pm 1$ \\
ISO1 S500D & $130 \pm 15$ \\
\hline
\end{tabular}

ed/dephosphorylated FMRP ISO1 to such G-quadruplex forming mRNA targets. Thus, it remains to be seen whether the S500D mutation does not affect the RNA binding properties of FMRP only in the context of its function of splicing factor or if this trend is also valid for G-quadruplex forming mRNAs whose translation is regulated directly by FMRP. It is possible that the protein phosphorylation does not play a role in the context of the FMRP function as a splicing factor or, alternatively, that FMRP phosphorylation might be important for FMRP function as a translation regulator and/or splicing factor by regulating its interactions with protein partners rather than with the RNA. Another possibility that has to be considered is that although the S500D has been used to mimic the translation regulator function of phosphorylated FMRP, the D mutation might not be a good substitution for a phosphorylated serine in the context of RNA binding due to the charge difference.

The $K_{\mathrm{d}}$ values for FMRP ISO2 and ISO3 binding to FBSsh_14AP RNA were also within error of each other, yet 
lower than those measured for ISO1 and ISO1 S500D (Table 2 ), indicating that the truncation of the protein in the proximity of the RGG box results in higher affinity binding for FMR1 mRNA. The same trend was also reported for the FMRP binding to the G-quadruplex forming semaphorin 3F mRNA, an mRNA target whose translation is postulated to be regulated by FMRP (Evans et al. 2012). All FMRP isoforms investigated in this study have an identical RGG box; thus, the difference in binding affinity of FMRP ISO1, ISO1 S500D, and ISO2, ISO3 to FBSsh_14AP RNA could be due to subtle conformational changes in the region proximal to the RGG box, which might result in its better orientation for binding G-quadruplex RNA.

FMRP ISO1 binding to the G-rich region within FMR1 has been shown to influence the splicing events at exon 15 by increasing the production of the isoforms $\mathrm{ISO} 2$ and ISO3, which lack the major phosphorylation site at position 500, and decreasing the production of FMRP ISO1 (Didiot et al. 2008). It has also been shown that $F M R 1^{-/-}$knockout mice, which produce FMR1 mRNA but not any FMRP protein, do not produce FMR1 mRNA that has been alternatively spliced at exon 15 (Didiot et al. 2008). Our findings that FMRP ISO2 and ISO3 isoforms bind FBSsh RNA with higher affinity than FMRP ISO1 suggest the existence of a feedback autoregulatory loop for the production of the FMRP ISO2 and ISO3: once sufficient amounts of FMRP ISO2 and ISO3 are produced by FMRP ISO1 binding to the FBS RNA sequence, they can compete with FMRP ISO1 for binding, possibly shutting down their own production. This might have implications for the translation regulator function of FMRP. In its phosphorylated state, FMRP has been shown to be associated with stalled polyribosomes (Ceman et al. 2003), and in the case of the PSD-95 mRNA target, with the RISC complex (Muddashetty et al. 2011), suggesting that in this state FMRP prevents the translation of its mRNA targets. The FMRP dephosphorylation in response to synaptic input has been shown to rescue the PSD-95 mRNA translation (Muddashetty et al. 2011). FMRP ISO2 and ISO3 isoforms do not have the ability to be regulated by phosphorylation/ dephosphorylation events. Our findings that they have higher affinity for G-quadruplex forming FMRP targets than FMRP ISO1 (this study; Evans et al. 2012) suggest a mechanism by which FMRP ISO2 and/or FMRP ISO3 could prolong the "on" state for translation of mRNA targets by competing with FMRP ISO1, which can turn "off" translation by becoming rephosphorylated. Thus, the levels of the different FMRP isoforms have to be tightly regulated in the cell as the expression of specific isoforms could control the timing of the translation of different FMRP mRNA targets.

The exact mechanism(s) by which FMRP ISO1 binding to the FBS region within FMR1 mRNA increases the usage of the second and third acceptor sites at exon 15 is not known. Several mechanisms that are not necessarily mutually exclusive could be envisioned: FMRP ISO1 might interact directly with splicing factors, recruiting them to FMR1 mRNA, or it might modulate the mRNA structure in such a way to make accessible/unaccessible the RNA binding sites for various splicing factors. We analyzed the entire 100-nt FBS sequence (1557-1658 within FMR1 mRNA, which contains FBSsh) with the SFmap software, which predicts and maps known splicing factor binding sites on RNA sequences (Akerman et al. 2009; Paz et al. 2010), identifying binding sites for several splicing factors (Supplemental Table 1). These splicing factors are members of the family of heterogeneous nuclear ribonucleoproteins (hnRNPs: hnRNP A1, hnRNP F, and hnRNP $\mathrm{H} 1$ ), or of the family of serine/arginine-rich proteins (SR) (SF2ASF and 9G8) or SR-like proteins (Tra2 $\alpha$ and Tra2 $\beta$ ). Both families of proteins are important in determining the splice site; in general, the hnRNP proteins antagonize SR and SR-like proteins' function. In many cases, these splicing factors have overlapping RNA binding sites, competing for binding the mRNA, and the FBS site within FMR1 mRNA is no exception (Supplemental Table 1). The finding that some of these splicing binding sites are embedded within the Gquadruplex structure formed by FBSsh (Supplemental Table 1 , bolded sequences) adds a new layer of complexity to the splicing mechanism, as when folded in this structure these sites are not available for binding by the corresponding splicing factors. An extensive search of the literature did not reveal any evidence about direct protein-protein interactions between FMRP and any of the splicing factors identified by the SFmap software (Supplemental Table 1), suggesting that FMRP might function to control the accessibility of the splicing factors to their RNA binding sites. Supporting this hypothesis are the findings that the binding of hnRNP F to its G-rich RNA binding site is limited by the stability of a G-quadruplex structure adopted by this sequence (Samatanga et al. 2012). Specifically, it has been shown that hnRNP F does not bind to the G-quadruplex structure formed by its G-rich binding site, and there is a competition between the formation of the G-quadruplex structure and of the hnRNP F protein-RNA complex. This situation could be similar in the case of the FMR1 mRNA, as the binding sites for hnRNP F are located within the FBS_Q1 quadruplex. Thus, in vivo, in the absence of FMRP, this sequence could adopt alternate structures (single-stranded versus G-quadruplex), whereas in the presence of FMRP, which binds G-quadruplex RNA, the G-quadruplex conformation could be favored, limiting the access of the hnRNP F splicing factor and ultimately influencing the splicing events in the proximity of this site within FMR1 mRNA.

\section{MATERIALS AND METHODS}

\section{In vitro RNA synthesis}

Unlabeled FBS_67 RNA, FBSsh RNA, FBS_Q1 RNA, and FBS_Q2 RNA (Table 1) oligonucleotides were synthesized in vitro off synthetic DNA templates (Trilink Biotechnologies, Inc.) using T7 RNA polymerase produced in-house (Milligan and Uhlenbeck 1989). Oligonucleotides were purified by $15 \%$ or $20 \% 8 \mathrm{M}$ urea denaturing polyacrylamide gel electrophoresis (PAGE), eluted using 
electrophoretic elution, and extensively dialyzed against $10 \mathrm{mM}$ cacodylic acid, pH 6.5 (Milligan and Uhlenbeck 1989). A fluorescent oligonucleotide was designed for FBSsh in which the highly fluorescent adenine analog 2AP replaced the adenine at position 14 of FBSsh RNA to construct FBSsh_14AP (Dharmacon, Inc.). Samples of FBS_67, FBS_Q1, and FBS_Q2 RNA sequences were annealed by heating at $95^{\circ} \mathrm{C}$ in the presence or absence of $\mathrm{KCl}$ and slow cooling for $30 \mathrm{~min}$ to $25^{\circ} \mathrm{C}$. All samples of FBSsh and FBSsh_14AP RNA were prepared by incubation in the presence or absence of $\mathrm{KCl}$ for $20 \mathrm{~min}$ at $25^{\circ} \mathrm{C}$.

\section{Expression of recombinant FMRP isoforms}

The recombinant pET21a-FMRP plasmid encoding FMRP isoform 1 (ISO1) fused with a C-terminal 6X histidine tag was a kind gift from Dr. Bernhard Laggerbauer (Institute of Pharmacology and Toxicology, Technische Universität München, Munich, Germany). The truncations of the FMR1 gene encoding for FMRP ISO1 to create the genes encoding for ISO2 and ISO3 were performed by GenScript USA, Inc. and confirmed by sequencing at the University of Pittsburgh Genomics and Proteomics Core (Evans et al. 2012). In order to recombinantly express, purify, and dialyze ISO2 and ISO3, we used previously developed protocols (Laggerbauer et al. 2001; Evans and Mihailescu 2010). In brief, plasmids were transformed into Rosetta2(DE3)pLysS E. coli cells. All media used in the cell growth consisted of Luria-Bertani (LB; Fisher Scientific) media containing $200 \mu \mathrm{g} / \mathrm{mL}$ ampicillin (AMP; MP Biomedical), and $15 \mu \mathrm{g} / \mathrm{mL}$ chloramphenicol (CHL; MP Biomedical). Cells were incubated at $37^{\circ} \mathrm{C}$ until the target O.D. of $0.8-1.0$ was reached, and protein expression was induced by adding $1 \mathrm{mM}$ isopropyl $\beta$-D-1-thiogalactopyranoside (IPTG) and incubating cells at $250 \mathrm{rpm}$ for $12 \mathrm{~h}$ at $25^{\circ} \mathrm{C}$. FMRP was purified using Ni-NTA Superflow resin (Qiagen) as described (Evans and Mihailescu 2010). Purified proteins were concentrated using dialysis tubing filled with polyethylene glycol (PEG) 20,000 and dialyzed into a buffer devoid of $\mathrm{K}^{+}, \mathrm{Na}^{+}$, or imidazole. Final protein buffer consisted of $20 \mathrm{mM}$ Hepes, 5\% glycerol, 1 $\mathrm{mM}$ EDTA, and $300 \mathrm{mM} \mathrm{LiCl}$. The concentration of FMRP isoforms was determined at $\mathrm{A}_{280}$ by using the molar extinction coefficients of $46,370 \mathrm{M}^{-1} \mathrm{~cm}^{-1}$ for ISO 1 and ISO2 and $40,680 \mathrm{M}^{-1} \mathrm{~cm}^{-1}$ for ISO3 (Evans and Mihailescu 2010).

FMRP ISO1 has been shown to be phosphorylated at three serine sites in exon 15, serine 500 being shown to be biologically relevant (Coffee et al. 2011; Muddashetty et al. 2011). We used a phosphomimetic version of FMRP ISO1 in which serine 500 was replaced by aspartic acid in order to mimic phosphorylation on serine 500 (Tarrant and Cole 2009). This phosphomimetic FMRP ISO1 S500D mutation was performed by GenScript USA, Inc. The concentration of FMRP ISO1 S500D was determined at $\mathrm{A}_{280}$ by using the molar extinction coefficients of $46,370 \mathrm{M}^{-1} \mathrm{~cm}^{-1}$. The presence of the FMRP isoforms was analyzed using a 10\% tris-glycine sodium dodecylsulfate-polyacrylamide gel electrophoresis (SDS-PAGE) and visualized by Coomassie blue staining.

\section{UV spectroscopy}

The melting curves of the RNA oligonucleotides were collected on a Varian Cary 3E spectrophotometer outfitted with a peltier temperature control cell holder. Experiments were carried out in a $10-\mathrm{mm}$ path length $200-\mu \mathrm{L}$ quartz cuvette (Starna Cells) using samples pre- pared as follows in $10 \mathrm{mM}$ cacodylic acid, $\mathrm{pH} 6.5$ up to a final volume of $200 \mu \mathrm{L}$. FBS_67 RNA, FBS_Q1 RNA, and FBS_Q2 RNA were all prepared by boiling for $10 \mathrm{~min}$ and cooling to $25^{\circ} \mathrm{C}$ for $30 \mathrm{~min}$. Samples of FBSsh RNA were prepared and incubated for $30 \mathrm{~min}$ at $25^{\circ} \mathrm{C}$. Samples were heated from $25^{\circ} \mathrm{C}$ to $95^{\circ} \mathrm{C}$ at a rate of $0.2^{\circ} \mathrm{C}$ per minute with points recorded every $1^{\circ} \mathrm{C}$. Samples and reference cells were covered with $200 \mu \mathrm{L}$ mineral oil to prevent evaporation of aqueous solutions at high temperatures. Spectral absorbance changes were monitored at either $295 \mathrm{~nm}$ or $305 \mathrm{~nm}$, wavelengths that have been identified as being sensitive to G-quadruplex dissociation, depending on the absorbance of the RNA at different concentrations (Mergny et al. 1998). All UV thermal denaturation experiments were performed in duplicate. In order to determine the inter- or intramolecular conformation of the G-quadruplex, melting temperatures of various concentrations of RNA between 3 and $50 \mu \mathrm{M}$ were recorded.

\section{Circular dichroism spectroscopy}

CD experiments were performed on a J-810 spectrapolarimeter at $25^{\circ} \mathrm{C}$ using a $200-\mu \mathrm{L}$ quartz cuvette with a $1-\mathrm{mm}$ path length (Starna Cells). Parallel G-quadruplex formation of the RNA oligonucleotides at $10 \mu \mathrm{M}$ in $10 \mathrm{mM}$ cacodylic acid, $\mathrm{pH}$ 6.5, was observed as $\mathrm{KCl}$ was titrated in increasing concentrations from a $2 \mathrm{M}$ stock, by monitoring the change in molar elipticity at $240 \mathrm{~nm}$ and $265 \mathrm{~nm}$. Each spectrum was scanned seven times from 200 to $350 \mathrm{~nm}$ with a $1-\mathrm{sec}$ response time and a $2-\mathrm{nm}$ bandwidth.

\section{${ }^{1}$ H NMR spectroscopy}

The one-dimensional (1D) ${ }^{1} \mathrm{H}-\mathrm{NMR}$ spectra of the RNA oligonucleotides were acquired at $25^{\circ} \mathrm{C}$ on a $500 \mathrm{MHz}$ Bruker AVANCE spectrometer. Water suppression was carried out by using the Watergate pulse sequence (Piotto et al. 1992). RNA oligonucleotides were prepared in $10 \mathrm{mM}$ cacodylic acid, $\mathrm{pH} 6.5$, in a 90:10 ratio of $\mathrm{H}_{2} \mathrm{O}: \mathrm{D}_{2} \mathrm{O}$. G-quadruplex formation was observed by titrating increasing concentrations of $\mathrm{KCl}$ form a $2 \mathrm{M}$ stock to each sample and allowing samples to equilibrate for $10 \mathrm{~min}$ at $25^{\circ} \mathrm{C}$. The $\mathrm{D}_{2} \mathrm{O}$ exchange experiment was carried out by lyophilizing the FBS_Q1 RNA sample and resuspending it in $250 \mu \mathrm{L}$ pure $\mathrm{D}_{2} \mathrm{O}$, with spectra measured in the interval $10 \mathrm{~min}$ to $5 \mathrm{~d}$ at $25^{\circ} \mathrm{C}$.

${ }^{1} \mathrm{H}-{ }^{1} \mathrm{H}$ two-dimensional (2D) homonuclear NOESY experiments with a mixing time of $50 \mathrm{msec}$ were acquired at $25^{\circ} \mathrm{C}$ in $90 \%: 10 \%$ $\mathrm{H}_{2} \mathrm{O}: \mathrm{D}_{2} \mathrm{O}$ with an RNA concentration of $1.1 \mathrm{mM}$ in $10 \mathrm{mM}$ cacodylic acid, pH 6.5 (Piotto et al. 1992; Sklenar et al. 1993). Data sets were processed using XWIN-NMR (Bruker).

\section{RGG box peptide synthesis}

The FMRP RGG box peptide with the sequence N-RRGDGRRR GGGGRGQGGRGRGGGFKGNDDHSR-C was chemically synthesized by the Peptide Synthesis Unit at the University of Pittsburgh Center for Biotechnology and Bioengineering.

\section{Native polyacrylamide gel electrophoresis}

FBS_67 RNA, FBS_Q1 RNA, and FBS_Q2 RNA were prepared by heating for $5 \mathrm{~min}$ at $95^{\circ} \mathrm{C}$ and allowing samples to cool for 
30 min to $25^{\circ} \mathrm{C}$. Samples of FBSsh RNA were prepared by incubation for $20 \mathrm{~min}$ at $25^{\circ} \mathrm{C}$. Gels were run at $4^{\circ} \mathrm{C}$ from 40 to $75 \mathrm{~V}$ for 4 to 6 h. Gels (15\% for FBSsh and FBS_67 RNA and 20\% for FBS_Q1 and FBS_Q2 RNA) were visualized by UV shadowing at $254 \mathrm{~nm}$ (Hendry and Hannan 1996) or staining in ethidium bromide or SYBR gold and visualized on an AlphaImager (AlphaInnotech). FMRP RGG box binding experiments were performed by preparing the RNA sequences as described above and then incubating samples with RGG box peptide in different ratios for an additional $30 \mathrm{~min}$ at $25^{\circ} \mathrm{C}$.

\section{Fluorescence spectroscopy}

Steady-state fluorescence spectroscopy experiments of FBSsh_14AP were performed on a Horiba Jobin Yvon Fluoromax-3 and accompanying software fitted with a $150 \mathrm{~W}$ ozone-free xenon arclamp. Experiments were performed in a $150-\mu \mathrm{L}$ sample volume, 3-mm path-length quartz cuvette (Starna Cells). Excitation wavelength was set to $310 \mathrm{~nm}$, the emission spectrum was recorded in the range of $330-450 \mathrm{~nm}$, and the bandpass for excitation and emission monochromators were both set to $3 \mathrm{~nm}$. For binding experiments, the temperature was set to $25^{\circ} \mathrm{C}$, and increasing concentrations of FMRP isoforms (ISO1, ISO2, ISO3, and ISO1 S500D) were titrated in $15 \mathrm{nM}$ increments to a fixed RNA concentration of $150 \mathrm{nM}$ in 10 mM cacodylic acid, $\mathrm{pH} 6.5$, and $25 \mathrm{mM} \mathrm{KCl}$. A ratio of 5:1 BSA:RNA was added to the RNA sample before titration to reduce nonspecific binding. Emission values were corrected for free protein emission of both BSA and FMRP isoforms, and the data were normalized to free RNA fluorescence intensity monitored at $371 \mathrm{~nm}$. Experiments were performed in triplicate, and the resulting averages of normalized intensity were plotted as a function of the FMRP isoform concentration and fitted to Equation 5. $I_{F}$ and $I_{B}$ represent steady-state fluorescence intensities of free and bound RNA, respectively; $[\mathrm{RNA}]_{t}$ is the total fixed RNA concentration; and $[P]_{t}$ is the total FMRP isoform concentration. The protein-RNA complex dissociation constant, $K_{\mathrm{d}}$, was determined for each experiment by fitting the binding curve with Equation 5:

$$
\begin{aligned}
& F=1+\left(\frac{I_{B}}{I_{F}}-1\right) \\
& \cdot \frac{\left(K_{d}+[P]_{t}+[\mathrm{RNA}]_{t}\right)-\sqrt{\left(K_{d}+[P]_{t}+[\mathrm{RNA}]_{t}\right)^{2}-4 \cdot[P]_{t} \cdot[\mathrm{RNA}]_{t}}}{2 \cdot[\mathrm{RNA}]_{t}} .
\end{aligned}
$$

These experiments were performed in triplicate for each FMRP isoform, and the reported errors represent the standard deviations of the dissociation constants determined from independent fits to the three measurements.

\section{SUPPLEMENTAL MATERIAL}

Supplemental material is available for this article.

\section{ACKNOWLEDGMENTS}

We thank Dr. Bernhard Laggerbauer (Institute of Pharmacology and Toxicology, Technische Universität München, Munich, Germany) for the plasmid pET21a-FMRP encoding for FMRP ISO1. This work was supported by the NIH Grants 2R15GM074660-02A1 and 9R15HD078017-03A1 to M.R.M.

Received July 18, 2013; accepted October 14, 2013.

\section{REFERENCES}

Akerman M, David-Eden H, Pinter RY, Mandel-Gutfreund Y. 2009. A computational approach for genome-wide mapping of splicing factor binding sites. Genome Biol 10: 30 .

Ashley CT, Sutcliffe JS, Kunst CB, Leiner HA, Eichler EE, Nelson DL, Warren ST. 1993. Human and murine FMR-1: Alternative splicing and translational initiation downstream of the CGG-repeat. Nat Genet 4: 244-251.

Bharill S, Sarkar P, Ballin JD, Gryczynski I, Wilson GM, Gryczynski Z. 2008. Fluorescence intensity decays of 2-aminopurine solutions: Lifetime distribution approach. Anal Biochem 377: 141-149.

Bole M, Menon L, Mihailescu MR. 2008. Fragile X mental retardation protein recognition of $G$ quadruplex structure per se is sufficient for high affinity binding to RNA. Mol Biosyst 4: 1212-1219.

Brackett DM, Qing F, Amieux PS, Sellers DL, Horner PJ, Morris DR. 2013. Fmrl transcript isoforms: Association with polyribosomes; regional and developmental expression in mouse brain. PLoS One 8: e58296.

Brown V, Jin P, Ceman S, Darnell JC, O’Donnell WT, Tenenbaum SA, Jin X, Feng Y, Wilkinson KD, Keene JD, et al. 2001. Microarray identification of FMRP-associated brain mRNAs and altered mRNA translational profiles in fragile X syndrome. Cell 107: 477-487.

Ceman S, O’Donnell WT, Reed M, Patton S, Pohl J, Warren ST. 2003. Phosphorylation influences the translation state of FMRP-associated polyribosomes. Hum Mol Genet 12: 3295-3305.

Coffee RL Jr, Williamson AJ, Adkins CM, Gray MC, Page TL, Broadie K. 2011. In vivo neuronal function of the fragile $\mathrm{X}$ mental retardation protein is regulated by phosphorylation. Hum Mol Genet 21: 900-915.

Crawford DC, Acuna JM, Sherman SL. 2001. FMR1 and the fragile X syndrome: Human genome epidemiology review. Genet Med 3:359-371.

Dapic V, Abdomerovic V, Marrington R, Peberdy J, Rodger A, Trent JO, Bates PJ. 2003. Biophysical and biological properties of quadruplex oligodeoxyribonucleotides. Nucleic Acids Res 31: 2097-2107.

Darnell JC, Jensen KB, Jin P, Brown V, Warren ST, Darnell RB. 2001. Fragile X mental retardation protein targets $G$ quartet mRNAs important for neuronal function. Cell 107: 489-499.

Didiot MC, Tian Z, Schaeffer C, Subramanian M, Mandel JL, Moine H. 2008. The G-quartet containing FMRP binding site in FMR1 mRNA is a potent exonic splicing enhancer. Nucleic Acids Res 36: $4902-4912$.

Evans TL, Mihailescu MR. 2010. Recombinant bacterial expression and purification of human fragile $\mathrm{X}$ mental retardation protein isoform 1. Protein Expr Purif 74: 242-247.

Evans TL, Blice-Baum AC, Mihailescu MR. 2012. Analysis of the Fragile $\mathrm{X}$ mental retardation protein isoforms 1,2 and 3 interactions with the G-quadruplex forming semaphorin 3F mRNA. Mol Biosyst 8: 642-649.

Gray RD, Chaires JB. 2011. Linkage of cation binding and folding in human telomeric quadruplex DNA. Biophys Chem 159: 205-209.

Guedin A, Gros J, Alberti P, Mergny JL. 2010. How long is too long? Effects of loop size on G-quadruplex stability. Nucleic Acids Res 38: $7858-7868$.

Hardin CC, Perry AG, White K. 2000. Thermodynamic and kinetic characterization of the dissociation and assembly of quadruplex nucleic acids. Biopolymers 56: 147-194.

Hawkins M, Boyle J, Wright KE, Elles R, Ramsden SC, O'Grady A, Sweeney M, Barton DE, Burgess T, Moore M, et al. 2011. Preparation and validation of the first WHO international genetic reference panel for Fragile X syndrome. Eur J Hum Genet 19: 10-17.

Hendry P, Hannan G. 1996. Detection and quantitation of unlabeled nucleic acids in polyacrylamide gels. Biotechniques 20: 258-264. 
Jin P, Warren ST. 2000. Understanding the molecular basis of fragile $\mathrm{X}$ syndrome. Hum Mol Genet 9: 901-908.

Jin P, Zarnescu DC, Ceman S, Nakamoto M, Mowrey J, Jongens TA, Nelson DL, Moses K, Warren ST. 2004. Biochemical and genetic interaction between the fragile $\mathrm{X}$ mental retardation protein and the microRNA pathway. Nat Neurosci 7: 113-117.

Kettani A, Gorin A, Majumdar A, Hermann T, Skripkin E, Zhao H, Jones R, Patel DJ. 2000. A dimeric DNA interface stabilized by stacked $A \cdot(G \cdot G \cdot G \cdot G) \cdot A$ hexads and coordinated monovalent cations. $J$ Mol Biol 297: 627-644.

Laggerbauer B, Ostareck D, Keidel EM, Ostareck-Lederer A, Fischer U. 2001. Evidence that fragile $X$ mental retardation protein is a negative regulator of translation. Hum Mol Genet 10: 329-338.

Lipay JM, Mihailescu MR. 2009. NMR spectroscopy and kinetic studies of the quadruplex forming RNA r(UGGAGGU). Mol Biosyst 5: $1347-1355$.

Liu H, Matsugami A, Katahira M, Uesugi S. 2002. A dimeric RNA quadruplex architecture comprised of two G:G(:A):G:G(:A) hexads, G:G: G:G tetrads and UUUU loops. J Mol Biol 322: 955-970.

Matsugami A, Mashima T, Nishikawa F, Murakami K, Nishikawa S, Noda K, Yokoyama T, Katahira M. 2008. Structural analysis of $r$ (GGA) $)_{4}$ found in RNA aptamer for bovine prion protein. Nucleic Acids Symp Ser (Oxf) 52: 179-180.

Menon L, Mihailescu MR. 2007. Interactions of the G quartet forming semaphorin 3F RNA with the RGG box domain of the fragile X protein family. Nucleic Acids Res 35: 5379-5392.

Menon L, Mader SA, Mihailescu MR. 2008. Fragile X mental retardation protein interactions with the microtubule associated protein $1 \mathrm{~B}$ RNA. RNA 14: 1644-1655.

Mergny JL, Phan AT, Lacroix L. 1998. Following G-quartet formation by UV-spectroscopy. FEBS Lett 435: 74-78.

Mergny JL, De Cian A, Amrane S, Webba da Silva M. 2006. Kinetics of double-chain reversals bridging contiguous quartets in tetramolecular quadruplexes. Nucleic Acids Res 34: 2386-2397.

Milligan JF, Uhlenbeck OC. 1989. Synthesis of small RNAs using T7 RNA polymerase. Methods Enzymol 180: 51-62.

Morton JE, Bundey S, Webb TP, MacDonald F, Rindl PM, Bullock S. 1997. Fragile X syndrome is less common than previously estimated. J Med Genet 34: 1-5.

Muddashetty RS, Nalavadi VC, Gross C, Yao X, Xing L, Laur O, Warren ST, Bassell GJ. 2011. Reversible inhibition of PSD-95 mRNA translation by miR-125a, FMRP phosphorylation, and mGluR signaling. Mol Cell 42: 673-688.

O'Donnell WT, Warren ST. 2002. A decade of molecular studies of fragile X syndrome. Annu Rev Neurosci 25: 315-338.

Paz I, Akerman M, Dror I, Kosti I, Mandel-Gutfreund Y. 2010. SFmap: A web server for motif analysis and prediction of splicing factor binding sites. Nucleic Acids Res 38: 281-285.

Pieretti M, Zhang FP, Fu YH, Warren ST, Oostra BA, Caskey CT, Nelson DL. 1991. Absence of expression of the FMR-1 gene in fragile X syndrome. Cell 66: 817-822.

Piotto M, Saudek V, Sklenar V. 1992. Gradient-tailored excitation for single-quantum NMR spectroscopy of aqueous solutions. J Biomol NMR 2: 661-665.
Samatanga B, Dominguez C, Jelesarov I, Allain FH. 2012. The high kinetic stability of a G-quadruplex limits hnRNP F qRRM3 binding to G-tract RNA. Nucleic Acids Res 41: 2505-2516.

Schaeffer C, Bardoni B, Mandel JL, Ehresmann B, Ehresmann C, Moine H. 2001. The fragile X mental retardation protein binds specifically to its mRNA via a purine quartet motif. $E M B O J \mathbf{2 0}$ 4803-4813.

Schaeffer C, Beaulande M, Ehresmann C, Ehresmann B, Moine H. 2003. The RNA binding protein FMRP: New connections and missing links. Biol Cell 95: 221-228.

Serrano-Andres L, Merchan M, Borin AC. 2006. Adenine and 2-aminopurine: Paradigms of modern theoretical photochemistry. Proc Natl Acad Sci 103: 8691-8696.

Siomi H, Siomi MC, Nussbaum RL, Dreyfuss G. 1993. The protein product of the fragile $\mathrm{X}$ gene, FMR1, has characteristics of an RNA-binding protein. Cell 74: 291-298.

Siomi MC, Higashijima K, Ishizuka A, Siomi H. 2002. Casein kinase II phosphorylates the fragile $\mathrm{X}$ mental retardation protein and modulates its biological properties. Mol Cell Biol 22: 84388447.

Sittler A, Devys D, Weber C, Mandel JL. 1996. Alternative splicing of exon 14 determines nuclear or cytoplasmic localisation of fmr 1 protein isoforms. Hum Mol Genet 5: 95-102.

Sklenar V, Peterson RD, Rejante MR, Feigon J. 1993. Two- and three-dimensional HCN experiments for correlating base and sugar resonances in 15N,13C-labeled RNA oligonucleotides. J Biomol NMR 3: 721-727.

Stetler A, Winograd C, Sayegh J, Cheever A, Patton E, Zhang X, Clarke S, Ceman S. 2006. Identification and characterization of the methyl arginines in the fragile $\mathrm{X}$ mental retardation protein Fmrp. Hum Mol Genet 15: 87-96.

Tarrant MK, Cole PA. 2009. The chemical biology of protein phosphorylation. Annu Rev Biochem 78: 797-825.

Tassone F, Hagerman RJ, Iklé DN, Dyer PN, Lampe M, Willemsen R, Oostra BA, Taylor AK. 1999. FMRP expression as a potential prognostic indicator in fragile X syndrome. Am J Med Genet 84: 250-261.

Verkerk AJ, de Graaff E, De Boulle K, Eichler EE, Konecki DS, Reyniers E, Manca A, Poustka A, Willems PJ, Nelson DL, et al. 1993. Alternative splicing in the fragile X gene FMR1. Hum Mol Genet 2: 1348 .

Wei D, Parkinson GN, Reszka AP, Neidle S. 2012. Crystal structure of a $c$-kit promoter quadruplex reveals the structural role of metal ions and water molecules in maintaining loop conformation. Nucleic Acids Res 40: 4691-4700.

Williamson JR. 1994. G-quartet structures in telomeric DNA. Annu Rev Biophys Biomol Struct 23: 703-730.

Williamson JR, Raghuraman MK, Cech TR. 1989. Monovalent cationinduced structure of telomeric DNA: The G-quartet model. Cell 59: $871-880$.

Zalfa F, Eleuteri B, Dickson KS, Mercaldo V, De Rubeis S, di Penta A, Tabolacci E, Chiurazzi P, Neri G, Grant SG, et al. 2007. A new function for the fragile $\mathrm{X}$ mental retardation protein in regulation of PSD-95 mRNA stability. Nat Neurosci 10: 578-587. 

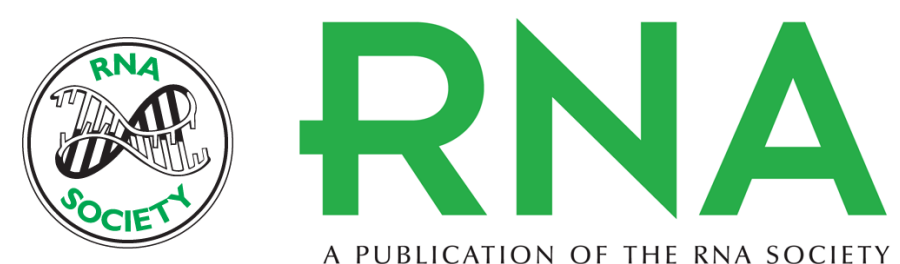

A PUBLICATION OF THE RNA SOCIETY

\section{Biophysical characterization of G-quadruplex forming FMR1 mRNA and of its interactions with different fragile $X$ mental retardation protein isoforms}

Anna C. Blice-Baum and Mihaela-Rita Mihailescu

RNA 2014 20: 103-114 originally published online November 18, 2013

Access the most recent version at doi:10.1261/rna.041442.113

Supplemental Material

References

Creative Commons License

Email Alerting Service
http://rnajournal.cshlp.org/content/suppl/2013/11/08/rna.041442.113.DC1

This article cites 53 articles, 5 of which can be accessed free at: http://rnajournal.cshlp.org/content/20/1/103.full.html\#ref-list-1

This article is distributed exclusively by the RNA Society for the first 12 months after the full-issue publication date (see http://rnajournal.cshlp.org/site/misc/terms.xhtml). After 12 months, it is available under a Creative Commons License (Attribution-NonCommercial 3.0 Unported), as described at http://creativecommons.org/licenses/by-nc/3.0/.

Receive free email alerts when new articles cite this article - sign up in the box at the top right corner of the article or click here.

To subscribe to $R N A$ go to:

http://rnajournal.cshlp.org/subscriptions 